\title{
Holocene bats (Mammalia, Chiroptera) from five caves of Central Apennines (Italy)
}

\author{
LeONARdo SALARI ${ }^{1} \&$ Letizia SilveSTRI ${ }^{2}$
}

\author{
${ }^{1}$ Dipartimento Scienze della Terra, "Sapienza" \\ Università di Roma, Viale Aldo Moro, 5 I-00185 Roma (Italy). \\ 2 Department of Archaeology, Durham University. \\ South Road, DH1 3LE Durham (United Kingdom).
}

*Corresponding author e-mail: leonardosalari@virgilio.it

DOI: http://dx.doi.org/10.14709/BarbJ.8.1.2015.06 C 2015 Published by SECEMU.

Spanish title: Murciélagos (Mammalia, Chiroptera) del Holoceno de cinco cuevas de los Apeninos Centrales (Italia)

\begin{abstract}
Sixteen taxa divided into three families (Rhinolophidae, Vespertilionidae and Miniopteridae) and seven genera (Rhinolophus, Myotis, Nyctalus, Plecotus, Barbastella, Miniopterus and Hypsugo vel Pipistrellus) have been recorded among the microvertebrate remains from five caves of the Central Apennines (Italy). Archaeological excavations were carried out in the caves Grotta Bella in Umbria, Grotta Continenza in Abruzzi, Grotta Mora Cavorso, Grotta Regina Margherita and Grotta di Pastena in Latium, over the last decades. The chronology of the sites spans from the early to middle Holocene (Mesolithic to the Bronze Age).

Taphonomic observations suggest that the majority of the bat assemblages examined are autochthonous thanatocoenoses. The microclimate of the caves and the surrounding paleoenvironments can be reconstructed on the basis of ecological attributes of these taxa. The relative abundance of bat remains in the cave sediments testifies to the absence or the sporadic presence of humans in these sites during the corresponding time spans. The occurrence of Rhinolophus mehelyi in Central Italy during the early and middle Holocene adds new information on the geographical distribution of this species in the past.
\end{abstract}

Keywords: Chiroptera, Holocene, Italy, ecology, microclimate, biogeography, human activities.

Resumen: En cinco cuevas de los Apeninos Centrales (Italia) han sido encontrados, entre los restos de microvertebrados, dieciséis taxones agrupados en 3 familias (Rhinolophidae, Vespertilionidae y Miniopteridae) y 7 géneros (Rhinolophus, Myotis, Nyctalus, Plecotus, Barbastella, Miniopterus y Hypsugo vel Pipistrellus). En estas cuevas (Grotta Bella en Umbría, Grotta Continenza en Abruzos, Grotta Mora Cavorso, Grotta Regina Margherita y Grotta di Pastena en Lazio) se llevaron a cabo excavaciones arqueológicas en las últimas décadas. Los yacimientos se extendien desde el Holoceno antiguo y medio (Mesolítico hasta la Edad del Bronce ).

Las observaciones tafonómicas sugieren que la mayoría de las comunidades de murciélagos analizadas son tanatocenosis autóctonas. Considerando las características ecológicas de estos taxones es posible reconstruir el microclima de las cuevas y el ambiente que constituye el entorno de los yacimientos. La abundancia relativa de los restos de murciélago hallados en el sedimento de las cuevas evidencia la ausencia o la esporádica presencia humana en estos sitios en los correspondientes intervalos de tiempo. La presencia de Rhinolophus mehelyi en Italia central durante el Holoceno antiguo y medio proporciona nueva información sobre la distribución geográfica de esta especie en el pasado.

Palabras clave: Chiroptera, Holoceno, Italia, ecología, microclima, biogeografía, actividades humanas. 


\section{INTRODUCTION}

European Chiroptera are flying insectivorous animals that react rapidly to climatic and environmental changes (Kowalski 1995, Rebello et al. 2010, Lanza 2012). Therefore, they are very useful for paleoecological reconstructions, and they are also good indicators for reconstruction of hypogean microclimates. Their abundance in the cave sediments testifies to the absence or the sporadic presence of prehistoric humans in these sites during the same time spans (Guillem Calatayud 1997, Rossina, 2006, Rossina et al. 2006, Salari \& Kotsakis 2011, López-García \& Sevilla 2012). On the other hand, they do not provide significant biochronological indications, and probably for this reason few people are interested in their systematic study (Salari \& Kotsakis 2011), particularly for the more recent past, the Holocene.

This paper aims to explore the environmental, microclimate and biogeographic information provided by the bat remains recovered from five caves of Central Italy (Fig. 1), as well as their interactions with humans. The caves are: Grotta Bella in Umbria, Grotta Continenza in Abruzzi, Grotta Mora Cavorso, Grotta Regina Margherita and Grotta di Pastena in Latium. The archaeological investigations carried out over the last decades allowed to recover lithic, bone and pottery finds referred to a time interval spanning the early and middle Holocene (between the Mesolithic and the Middle Bronze Age), from Preboreal to Subboreal chronozones (Mangerud et al. 1974, Orombelli \& Ravazzi 1996). Stratigraphic sequences of these caves also include Upper Palaeolithic and/or historical layers that are not considered in this work.

\section{STRATIGRAPHIC NOTES}

\section{GrotTA Bella}

The cave is located on the slopes of Mount Aiola, in the Amerini Mountains, at $530 \mathrm{~m}$ a.s.1., about $2 \mathrm{~km}$ from Santa Restituta in Avigliano Umbro (Terni, Umbria).

The cave consists of a vast, almost semi-circular chamber (about $25 \times 30 \mathrm{~m}$ ) with a floor sloping towards the bottom with a gradient of about $32 \%$. The analysed material was recovered during archaeological excavations carried out by the "Soprintendenza per i Beni Archeologici dell'Umbria" in collaboration with the Palaethnology Institute of the University of Milan between 1970 and 1973. The excavations have shown evidence of human presence from the Neolithic to the Roman age. After a preliminary survey, three trenches (I, II and III) were opened; of these, the third (III) has revealed the best preserved stratigraphy. Below a remarkably thick layer of approximately $3 \mathrm{~m}$ (which contained archaeological and faunal finds related to the Imperial and Republican Age, the Iron Age and the Bronze Age), Neolithic levels were recognised, sealed by a thin soil layer concretioned and reddened by fire. The Neolithic levels are characterized by a first layer (about $1.65 \mathrm{~m}$ thick) of compact soil reddened by fire, followed by a crumbly gray soil with abundant sharpedged debris, large charcoal fragments and trichromatic painted pottery; finally, a dark layer (about $1.25 \mathrm{~m}$ thick) with charcoal fragments, increasingly abundant stones and linear pottery was identified (Guerreschi et al. 1992, Curci et al. 2010, 2014).
In the Stratigraphic Units (SSUU; Harris 1979) referred to the Neolithic and the Bronze Age, remains of Erinaceus europaeus, Lepus europaeus, Glis glis, Eliomys quercinus, Arvicola amphibius, Microtus (Terricola) savii, Clethrionomys glareolus, Apodemus sylvaticus vel flavicollis, Vulpes vulpes, Ursus arctos, Martes martes, Meles meles, Felis silvestris, Lynx linx, Cervus elaphus, Capreolus capreolus, Sus scrofa, S. domesticus, Bos taurus, Ovis aries vel Capra hircus, undetermined amphibians, reptiles and birds (Curci et al. 2010, 2014, Salari 2014, in press) and also of Myotis bechsteini, M. capaccinii and Miniopterus schreibersii (Tables 1 and 2) were recovered. The minimum number of individuals (MNI) of the nonvolant micromammals from the Bronze Age SSUU is 46 (Salari 2014), therefore bats make $11.5 \%$ of the total of micromammals from these SSUU.

In the Amerini Mountains area, Rhinolophus ferrumequinum and $R$. hipposideros have been currently reported (Natura 2000 Database IT5220008).

\section{Grotta Continenza}

The cave is situated on the slopes of Mount Labbrone, $710 \mathrm{~m}$ a.s.1., along the southern slope of the Fucino basin, next to the village of Trasacco (L'Aquila, Abruzzi).

Archaeological digs, started in 1978 and directed by the Archaeology Department of the University of Pisa, uncovered several human remains, as well as one of the most complete stratigraphic sequences ranging from final Epigravettian and the Neolithic (Barra et al. 1990, Bevilacqua 1994).

In the Mesolithic and Neolithic layers Erinaceus europaeus, Crocidura suaveolens, C. leucodon, Sorex gr. arenaus-samniticus, Lepus europaeus, Marmota marmota, Glis glis, Eliomys quercinus, Microtus (Terricola) savii, Clethrionomys glareolus, Apodemus (Sylvaemus) sp., A. (S.) sylvaticus, A. (S.) flavicollis, Canis lupus, C. familiaris, Vulpes vulpes, Martes sp., Meles meles, Lutra lutra, Felis silvestris, Ursus arctos, Sus scrofa, S. domesticus, Cervus elaphus, Capreolus capreolus, Bos primigenius, B. taurus, Rupicapra sp., Capra ibex, C. hircus, Ovis aries and various bird, fish and mollusc species were found (Barra et al. 1990; Bevilacqua 1994, Di Canzio 2004), along with Rhinolophus ferrumequinum, R. mehelyi, $R$. euryale, R. hipposideros, Myotis myotis, M. blythii, M. capaccinii, M. emarginatus, Myotis sp., Hypsugo vel Pipistrellus, Nyctalus noctula, Barbastella barbastellus and Miniopterus schreibersii (Tables 1 and 2). In the Mesolithic spits, the remains of 230 individuals were found belonging to rodents and soricomorphs, and in the Neolithic spits, 89 individuals were counted (Di Canzio 2004); hence the bats make 15.1 and $17.6 \%$ of the micromammal individuals respectively.

Currently, several bat species, such as $R$. ferrumequinum, $R$. hipposideros, M. myotis, M. brandtii, B. barbastellus and $M$. schreibersii are recorded in the neighbouring Abruzzi National Park (Natura 2000 Database IT7110205; Agnelli et al. 2006). 


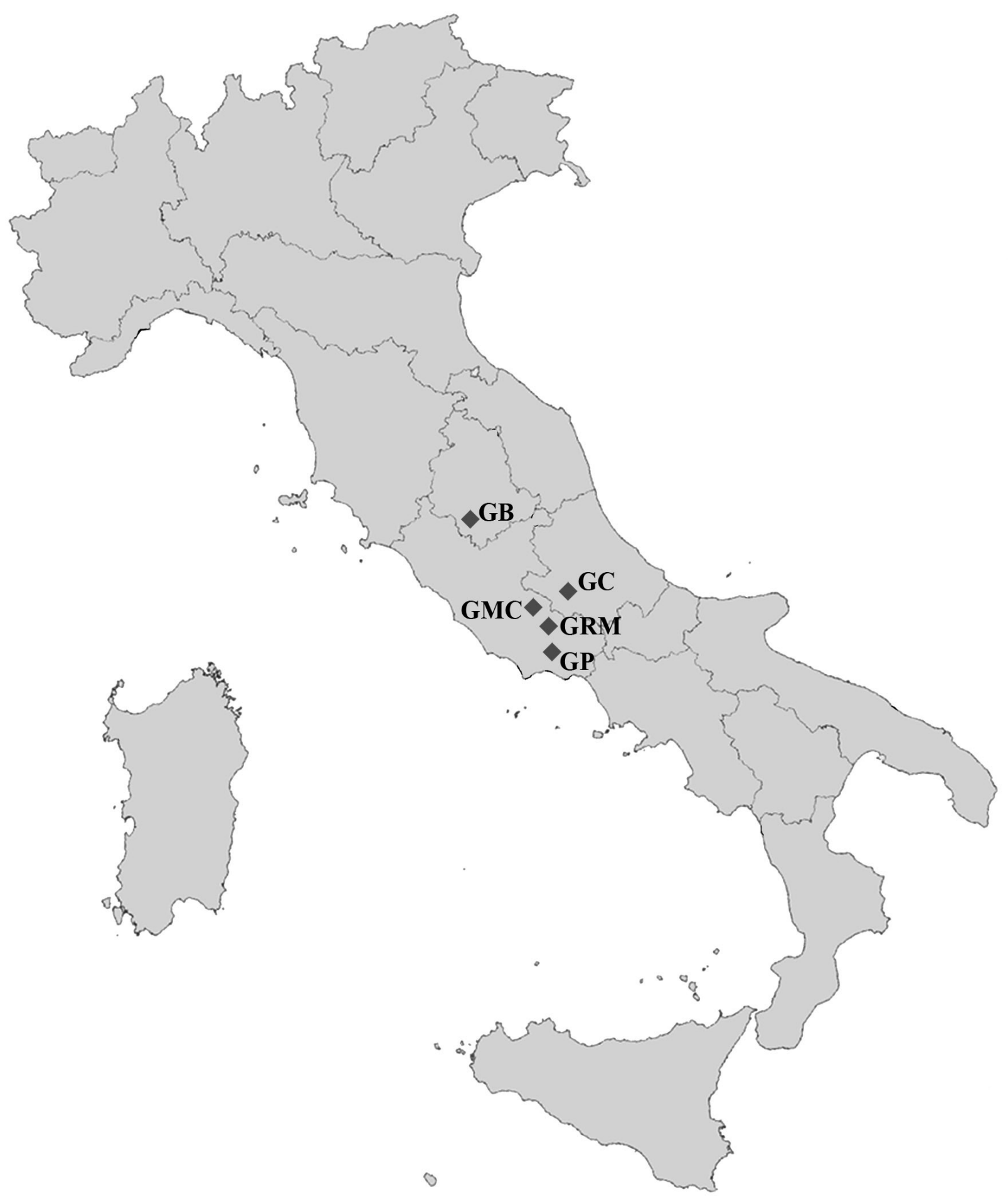

Fig. 1 - Location of the sites. GB: Grotta Bella; GC: Grotta Continenza; GMC: Grotta Mora Cavorso; GRM: Grotta Regina Margherita; GP: Grotta di Pastena.

\section{Grotta Mora Cavorso}

The cave is located at $715 \mathrm{~m}$ a.s.l., in Palo Montano locality, near Jenne (Rome, Latium) and faces the right side of the upper Aniene River valley in the Regional Natural Park of the Simbruini Mountains.

The cave presents a succession of chambers and passages. At the end of the chamber 1 (about $20 \times 10 \mathrm{~m}$ ) a narrow passage leads to a natural duct with a $20^{\circ}$ gradient. At the end of the duct the first inner room (about $6 \times 4$ $\mathrm{m}$ ) is found, covered by stalagmite crusts. On the north wall, a second, horizontal natural duct is present, strongly concreted, and about $20 \mathrm{~m}$ long. At the end of it, two chambers (Upper and Lower) containing human remains were found. Archaeological investigations started in 2006 by the University of Rome "Tor Vergata", in agreement with the "Soprintendenza per i Beni Archeologici del Lazio", and focused initially on the areas with the human remains (at least 21 individuals spread over about $10 \mathrm{sq} \mathrm{m}$ ) referred to the early Neolithic, fully incorporated into stalagmite crusts. Subsequently, several digs were opened with the purpose of investigating the stratigraphical sequence of 
Table 1 - Number of identified specimens (NISP) of taxa identified and their percentage reports. GC: Grotta Continenza; GMC: Grotta Mora Cavorso; GB: Grotta Bella; GRM: Grotta Regina Margherita; GP: Grotta di Pastena. M: Mesolithic; N: Neolithic; B: Bronze Age.

\begin{tabular}{|c|c|c|c|c|c|c|c|c|c|c|c|c|c|c|}
\hline \multirow{3}{*}{ Species/NISP } & $\mathrm{GC}$ & $\mathrm{GC}$ & $\mathrm{GC}$ & $\mathrm{GC}$ & GMC & GMC & GMC & GMC & GB & GB & GRM & GRM & GP & GP \\
\hline & $\mathrm{M}$ & $\mathrm{M}$ & $\mathrm{N}$ & $\mathrm{N}$ & $\mathrm{N}$ & $\mathrm{N}$ & NB & NB & B & B & B & B & B & B \\
\hline & $\mathrm{n}$. & $\%$ & $\mathrm{n}$. & $\%$ & $\mathrm{n}$. & $\%$ & $\mathrm{n}$. & $\%$ & n. & $\%$ & $\mathrm{n}$. & $\%$ & $\mathrm{n}$. & $\%$ \\
\hline Rhinolophus ferrumequinum & 17 & 20,7 & 15 & 35,7 & 2 & 28,6 & 8 & 61,5 & & & 15 & 42,9 & & \\
\hline Rhinolophus euryale & 1 & 1,2 & 1 & 2,4 & & & & & & & 2 & 5,7 & & \\
\hline Rhinolophus mehelyi & 1 & 1,2 & & & & & & & & & & & & \\
\hline Rhinolophus euryale/mehelyi & & & 1 & 2,4 & & & & & & & & & & \\
\hline Rhinolophus hipposideros & 1 & 1,2 & & & 2 & 28,6 & 1 & 7,7 & & & 1 & 2,9 & & \\
\hline Myotis myotis & 1 & 1,2 & & & & & 1 & 7,7 & & & 7 & 20,0 & & \\
\hline Myotis blythii & 30 & 36,6 & 11 & 26,2 & 2 & 28,6 & 1 & 7,7 & & & 6 & 17,1 & 3 & 100 \\
\hline Myotis myotis/blythi & 1 & 1,2 & 1 & 2,4 & 1 & 14,3 & & & & & & & & \\
\hline Myotis bechsteini & & & & & & & & & 4 & 40,0 & & & & \\
\hline Myotis capaccinii & 15 & 18,3 & 10 & 23,8 & & & & & 5 & 50,0 & & & & \\
\hline Myotis emarginatus & 1 & 1,2 & & & & & & & & & & & & \\
\hline Myotis mystacinus s.l. & & & & & & & & & & & 1 & 2,9 & & \\
\hline Myotis sp. & 6 & 7,3 & & & & & & & & & & & & \\
\hline Hypsugo vel Pipistrellus & 1 & 1,2 & & & & & & & & & & & & \\
\hline Nyctalus noctula & & & 1 & 2,4 & & & & & & & & & & \\
\hline Plecotus auritus s.l. & & & & & & & 1 & 7,7 & & & & & & \\
\hline Barbastella barbastellus & 2 & 2,4 & & & & & & & & & & & & \\
\hline Miniopterus schreibersii & 5 & 6,1 & 2 & 4,8 & & & 1 & 7,7 & 1 & 10,0 & 3 & 8,6 & & \\
\hline total NISP & 82 & & 42 & & 7 & & 13 & & 10 & & 35 & & 3 & \\
\hline total taxa & 12 & & 8 & & 4 & & 6 & & 3 & & 7 & & 1 & \\
\hline
\end{tabular}

Table 2 - Minimum number of individuals (MNI) of taxa identified and their percentage reports. For abbreviations see Tab.1 caption.

\begin{tabular}{|c|c|c|c|c|c|c|c|c|c|c|c|c|c|c|}
\hline \multirow{3}{*}{ Species/MNI } & GC & $\mathrm{GC}$ & GC & $\mathrm{GC}$ & GMC & GMC & GMC & GMC & GB & GB & GRM & GRM & GP & GP \\
\hline & M & M & $\mathrm{N}$ & $\mathrm{N}$ & $\mathrm{N}$ & $\mathrm{N}$ & NB & NB & $\mathrm{B}$ & $\mathrm{B}$ & $\mathrm{B}$ & $\mathrm{B}$ & $\mathrm{B}$ & B \\
\hline & $\mathrm{n}$. & $\%$ & $\mathrm{n}$. & $\%$ & $\mathrm{n}$. & $\%$ & $\mathrm{n}$. & $\%$ & $\mathrm{n}$. & $\%$ & $\mathrm{n}$. & $\%$ & $\mathrm{n}$. & $\%$ \\
\hline Rhinolophus ferrumequinum & 8 & 19,5 & 6 & 31,6 & 1 & 25,0 & 5 & 50,0 & & & 8 & 36,4 & & \\
\hline Rhinolophus euryale & 1 & 2,4 & 1 & 5,3 & & & & & & & 1 & 4,5 & & \\
\hline Rhinolophus mehelyi & 1 & 2,4 & & & & & & & & & & & & \\
\hline Rhinolophus euryale/mehelyi & & & 1 & 5,3 & & & & & & & & & & \\
\hline Rhinolophus hipposideros & 1 & 2,4 & & & 1 & 25,0 & 1 & 10,0 & & & 1 & 4,5 & & \\
\hline Myotis myotis & 1 & 2,4 & & & & & 1 & 10,0 & & & 5 & 22,7 & & \\
\hline Myotis blythii & 12 & 29,3 & 5 & 26,3 & 1 & 25,0 & 1 & 10,0 & & & 4 & 18,2 & 2 & 100 \\
\hline Myotis myotis/blythi & & & & & 1 & 25,0 & & & & & & & & \\
\hline Myotis bechsteini & & & & & & & & & 2 & 33,3 & & & & \\
\hline Myotis capaccinii & 7 & 17,1 & 5 & 26,3 & & & & & 3 & 50,0 & & & & \\
\hline Myotis emarginatus & 1 & 2,4 & & & & & & & & & & & & \\
\hline Myotis mystacinus s.l. & & & & & & & & & & & 1 & 4,5 & & \\
\hline Myotis sp. & 3 & 7,3 & & & & & & & & & & & & \\
\hline Hypsugo vel Pipistrellus & 1 & 2,4 & & & & & & & & & & & & \\
\hline Nyctalus noctula & & & 1 & 5,3 & & & & & & & & & & \\
\hline Plecotus auritus s.l. & & & & & & & 1 & 10,0 & & & & & & \\
\hline Barbastella barbastellus & 1 & 2,4 & & & & & & & & & & & & \\
\hline Miniopterus schreibersii & 4 & 9,8 & 1 & 5,3 & & & 1 & 10,0 & 1 & 16,7 & 2 & 9,1 & & \\
\hline total MNI & 41 & & 19 & & 4 & & 10 & & 6 & & 22 & & 2 & \\
\hline
\end{tabular}

the deposit. In particular, Digs B, C and D (in chamber 1, in chamber 2 and in the duct that connects them) held, with some discontinuities, archaeological findings from the Upper Palaeolithic to the historical age. In some layers of compact silty ground, intercalated with thin stalagmite concretions and containing, in places, limestone clasts with sharp edges, lithic artefacts were found (from Upper Paleolithic to middle Bronze Age), pottery (from Neolithic to the historical age), disarticulated human bones (only in the middle Bronze Age), faunal remains, charcoal fragments and ash (in all layers) (Rolfo et al. 2012a, 2013, Salari et al. 2011, 2012, Silvestri et al., in press). The Neolithic finds from Digs B, C and D were attributed to the early Neolithic and late Neolithic, but study of the stratigraphic sequence is still in progress.

The SSUU related to the Neolithic and the Bronze Age held the remains of Talpa caeca, Lepus sp., Glis glis, Eliomys quercinus, Arvicola amphibius, Microtus (Microtus) arvalis, 
M. (Terricola) savii, Clethrionomys glareolus, Apodemus sylvaticus vel flavicollis, Canis lupus, C. familiaris, Vulpes vulpes, Martes martes vel foina, Meles meles, Lutra lutra, Felis silvestris, Cervus elaphus, Capreolus capreolus, Sus scrofa, S. domesticus, Bos taurus, Ovis aries, Capra hircus, undetermined amphibians, reptiles and birds (Rolfo et al. 2012a, 2013, Salari et al. 2012, Salari 2014) and also of Rhinolophus ferrumequinum, R. hipposideros, Myotis myotis vel blythii, M. blythii, M. myotis, Plecotus auritus s.l. and Miniopterus schreibersii (microvertebrates found from 2006 to 2008 only) (Tables 1 and 2). The MNI of the non-volant micromammals is 18 in the burial area and 15 in Digs B, C and D (Salari 2014), therefore the bats represent 18.2 and $40.0 \%$ of the micromammal individuals found in the various areas investigated.

Today, in the different karstic caves of the Regional Natural Park of Simbruini Mountains, $R$. euryale, $R$. ferrumequinum, R. hipposideros, M. myotis, Eptesicus serotinus and M. schreibersii occur (Papi 2004); Grotta Mora Cavorso is frequented by a small colony of $R$. hipposideros.

\section{Grotta Regina Margherita}

The cave is located on the southern side of the cliff on top of which is the village of Collepardo (Frosinone, Latium), in the Ernici Mountains, about $30 \mathrm{~m}$ above Fiume creek, a tributary of the Cosa River.

The cave consists of a large chamber of about $90 \times 60 \mathrm{~m}$ that reaches $20 \mathrm{~m}$ in height, and is divided into three sectors of increasingly higher level, delimitated by impressive stalagmite columns; to the east of the entrance is a branch with a length of about $20 \mathrm{~m}$. This karst cave, recorded at the end of the $19^{\text {th }}$ Century under the name "Grotta dei Bambocci", is known in the literature for the excavations by Ponzi, for the Pleistocene faunal remains found by Segre in the last century and, later, for the pottery referred to the beginning of the Middle Bronze Age published by Biddittu and Guidi (Angle et al. 2010b, with references). The material examined comes from five test pits dug in different areas of the cave by the "Soprintendenza per i Beni Archeologici del Lazio" in 2008. Digs A (8 sq m), B (3 sq m), C (1 sq m), D (9 sq m) and $\mathrm{E}(1 \mathrm{sq} \mathrm{m})$ held human bones referred to 31 individuals and several archaeological and faunal finds that testify to intense human frequentation during the early Middle Bronze Age (Angle et al. 2010b). A joint collaboration between the "Soprintendenza per i Beni Archeologici del Lazio" and the University of Durham has resumed the investigations in 2014.

Preliminary analysis of the faunal remains recovered in 2008 has documented the presence of Ovis aries vel Capra hircus, Bos sp., Equus sp., Canis sp., Lepus sp., Vulpes sp., undetermined amphibians and birds (Angle et al. 2010b), Crocidura leucodon, Talpa caeca, Glis glis, Eliomys quercinus, Muscardinus avellanarius, Arvicola amphibius, M. (Terricola) savii, Microtus sp., Clethrionomys glareolus, Apodemus sylvaticus vel favicollis and Rattus rattus (Salari 2014) and also of Rhinolophus ferrumequinum, R. euryale, R. hipposideros, Myotis myotis, M. blythii, M. mystacinus s.l. and Miniopterus schreibersii (Tables 1 and 2). The MNI of rodents and soricomorphs is 93 (Salari 2014), therefore bats in this cave make $19.1 \%$ of micromammal individuals.
Presently, R. ferrumequinum, $R$. euryale, $R$. hipposideros, Myotis capaccinii, M. myotis e M. schreibersii occur in the cave (Natura 2000 Database IT6050006).

\section{Grotta di Pastena}

The cave is located $310 \mathrm{~m}$ a.s.l., in the Cretaceous limestones of the S. Cataldo Mount, in the Ausoni Mountains, adjacent to the Province Road that leads from Castro dei Volsci to Pastena (Frosinone, Latium).

Archaeological interest in this site has been known since the earliest investigations carried out in the 1980s (Angle et al., 2010a with references). Remains of Ovis aries vel Capra hircus, Bos sp., Sus sp., Felis sp. Emys sp., undetermined birds and molluscs come from the various test pits dug in 2008 by the "Soprintendenza per i Beni Archeologici del Lazio" (Angle et al. 2010a). A joint collaboration between the "Soprintendenza per i Beni Archeologici del Lazio" and the University of Rome "Tor Vergata" has resumed the investigations at the site in 2013 (Angle et al. 2014).

Among the micromammal remains found in 2008 in the sediments of the niche "E10", referred to the Middle Bronze Age, the only specimens taxonomically identified are an upper incisor of a medium-large sized rodent, along with an intact humerus and two distal portions of humerus attributed to M. blythii (Tables 1 and 2).

Currently, R. ferrumequinum, $R$. euryale, $R$. hipposideros, M. myotis, M. blythii and Miniopterus schreibersii live in this karst cave (Natura 2000 Database IT6050022).

\section{MATERIALS AND METHODS}

The material from Grotta Regina Margherita, Grotta di Pastena and Grotta Mora Cavorso (Digs B, C and D) was sieved with a 2-mm mesh in the field (smaller screens require the use of water, which was absent or scarce at the sites) and relatively good samples of bat remains were obtained. Because of difficulty separating the bones from the stalagmite crusts, only selected elements (mainly humeri) were recovered from the burial area of Grotta Mora Cavorso. The collection methods for the microvertebrate remains from Grotta Bella and Grotta Continenza are not known.

The bat remains were compared with osteological material, both fossil and recent, stored in the Department of Earth Sciences of the University of Rome "Sapienza", in the Department of Geological Sciences of the "Roma Tre" University and in the Laboratory of Archaeozoology of the National Museum of Prehistory and Ethnography "Luigi Pigorini" of Rome. The morphological and morphometric observations and the dichotomous keys given by Miller (1912), Lanza (1959, 2012), Felten et al. (1973), Sevilla García (1986; 1988), Ruedi et al. (1990), Niethammer \& Krapp (2001), Benda et al. (2003), Csorba et al. (2003) and Salari (2004) were also consulted. The analyses were performed with a stereoscopic microscope Nikon SMZ-U in the Department of Geological Sciences of the "Roma Tre" University.

For the taphonomic observations, the samples were considered in toto, while for the taxonomic determinations the analyzed material was chosen on the basis of its systematic 
importance (skull, maxilla, mandible and humerus). Other skeletal parts (e.g., scapula, radius, metacarpal bones, coxal) that enable identification at family or genus level or even species level, were not considered in order to minimize the statistical bias for small-bodied species. Their fragile skeletal elements are more frequently subject to the processes of differential destruction than those of larger species, or can be lost during collection. The minimum number of individuals (MNI) was calculated using the most represented side (right or left) of maxillae, mandibles and humeri; this result was integrated with the analysis of the age and the dimensional characters of the other skeletal elements.

The environmental reconstructions are based on actual studies on the ecology and biogeography of the taxa found in the different levels of the caves (Lanza 1959, 2012, Horáček et al. 2000, Niethammer \& Krapp 2001; Lanza \& Agnelli 2002, Agnelli et al. 2006). Holocene chronostratigraphy follows Orombelli \& Ravazzi (1996), supplemented by Ravazzi (2003).

\section{SYSTEMATIC NOTES}

In this work we follow the taxonomic and geographic synthesis by Simmons (2005), with the following exceptions.

- Family Miniopteridae is considered distinct from Vespertilionidae, according to Mein \& Tupinier (1977), Lanza \& Agnelli (2002), Agnelli et al. (2006), MillerButterworth et al. (2007) and Lanza (2012).

- We use the taxon M. blythii instead of M. oxygnathus. According to Simmons (2005), the extant European and Near-Eastern populations, up to North and West Iran, should be ascribed to $M$. oxygnathus as opposed to $M$. blythii oxygnathus or to M. blythii (Lanza 2012). However, the vast majority of the paleontological works examined identifies the remains of large-sized Myotis, distinct from M. myotis, as M. blythii (not as M. oxygnathus). In the Western Paleartic, M. blythii fossils date back to Pliocene (Salari et al. 2013 with references).

With respect to the distinction between the large-bodied Myotis (excluding M. punicus for palaeobiogeographic reasons), M. myotis is larger in size, but the dimensions of large M. blythii and small M. myotis overlap (Sevilla 1988, Niethammer \& Krapp 2001, Ghazali 2009). The only certain morphological difference between the teeth of M. myotis and $M$. blythii occurs on the talonid of $\mathrm{m} 3$, which is more reduced in M. myotis (Topál \& Tusnadi 1963, Sevilla 1986, 1988). Therefore we calculated the talonid reduction index (TRI $=$ talonid width $\times 100 /$ tooth length) and we assigned the specimens with the TRI less to 0.45 to M. myotis, and those with TRI close to 0.50 to M. blythii (Mein 1975). The dimensions of other specimens (Table 4) support our attribution (Ruedi et al. 1990, Niethammer \& Krapp 2001, Benda et al. 2003, Lanza 2012).

Concerning the humeri of identical morphology (Felten et al. 1973), discrimination between the two species mainly relied on the distal epiphysis, ascribing only the larger ones and those of more robust aspect to M. myotis, with all remaining material being assigned to $M$. blythii.
In Tables 1 and 2, percentages of the number of identified specimens (NISP) and of the minimum number of individuals (MNI) from the different caves are recorded; in Table 1 the number of identified taxa is also recorded. It can be immediately noted that the data differ considerably from site to site: some caves, such as Grotta Continenza and partly Grotta Regina Margherita, held a large number of remains, whereas others, such as Grotta di Pastena, held a rather limited number of bones.

The bat remains from the investigated caves do not show major morphological or morphometric differences from other Holocene and living species (Tables 3 and 4). However, the recent applications of modern bioacoustic and molecular biology techniques (combined with conventional approaches based on morphological and morphometric criteria), have allowed identification of new species. In particular, some subspecies or geographic varieties of species belonging to the genera Pipistrellus, Myotis and Plecotus (e.g., Pipistrellus pygmaeus, Myotis alcathoe, M. aurascens, M. punicus, Plecotus gaisleri, P. kolombatovici, P. macrobullaris, $P$. sardus) were elevated to the rank of full species (Agnelli et al. 2006, Lanza 2012), but the lack of sound morphometric data for their taxonomic determination did not permit adequate assessment of them. The fossil remains potentially falling into the above taxa were attributed to the traditionally recognised species, followed by s.l. (= sensu lato) in accordance with Agnelli et al. (2006) for reports of these taxa prior to 2000. This is the case of humeri of M. mystacinus s.l. (i.e. M. mystacinus or M. brandtii or M. alcathoe) from Grotta Regina Margherita and of Plecotus auritus s.l. (i.e. P. auritus or P. macrobullaris) from Grotta Mora Cavorso.

Distinction between Hypsugo savii and the species of larger size of the genus Pipistrellus is also problematic: the morphology and size of the distal epiphysis of the humeri are identical (Felten et al. 1973) and the humerus from Grotta Continenza was attributed to Hypsugo vel Pipistrellus (i.e. H. savii or P. kuhlii or P. nathusii). The attribution of a distal humerus of a medium-sized Rhinolophus species collected in Grotta Continenza is uncertain because the morphology of the specimen missing the styloid process does not allow assignment the bone to species level, and the dimensions fall inside the range of both Rhinolophus euryale and $R$. mehelyi (Felten et al. 1973). The attribution of some distal humeri of medium/small-sized Myotis from Grotta Continenza is also uncertain, because the morphology and breadth $(2.6-2.7 \mathrm{~mm})$ of the distal epiphysis of the humerus of Myotis daubentonii, $M$. emarginatus and $M$. nattereri are identical (Felten et al. 1973), and these remains are reported as "Myotis sp." in Tables 1 and 2; instead, a complete humerus was attributed to M. emarginatus. Finally, a few, highly fragmented bones of large-sized Myotis from Grotta Mora Cavorso and Grotta Continenza were attributed to Myotis myotis vel blythii, and a few toothless fragmented mandibles of medium/small-sized Myotis from Grotta Continenza is reported as "Myotis sp.".

\section{TAPHONOMY}

Bats are nocturnal animals and can be occasional prey of nocturnal birds of prey (Strigiformes), such as the longeared owl, Asio otus, the tawny owl, Strix aluco, the little owl, Athene noctua, the Eurasian eagle-owl, Bubo bubo and 
Table 3 - Rhinolophidae: osteometric measurements ( $\mathrm{mm}$ ). Abbreviations for skull, mandible and humerus dimensions: L. = maximum length; $\mathrm{ZB}=$ zygomatic breadth; $\mathrm{IcB}=$ breadth of interorbital constriction; $\mathrm{C}-\mathrm{C}=$ rostral width between upper canines (incl.); M3-M3 = rostral width between third upper molars (incl.); C-M3 = length of upper tooth-row between $\mathrm{C}$ and M3 (incl.); M1-M3 = length of upper molars (incl.); c-m3 = length of lower tooth-row between c and m3 (incl.); m1-m3 = length of lower molars; $\mathrm{Bd}=$ distal breadth of humerus. Other abbreviations: $\min =$ minimum; $\max =\operatorname{maximum}$; $\operatorname{mea}=$ mean; s.d. = standard deviation. Only humerus measurements were taken by Felten et al. (1973).

\begin{tabular}{|c|c|c|c|c|c|c|c|c|c|c|c|c|}
\hline \multirow{3}{*}{ Species/measurements } & \multicolumn{7}{|c|}{ early and middle Holocene bats of Italy } & \multicolumn{5}{|c|}{ European extant bats } \\
\hline & \multicolumn{5}{|c|}{$\begin{array}{l}\text { Five caves of Central Appennine (this } \\
\text { work) }\end{array}$} & \multicolumn{2}{|c|}{ Salari 2011} & \multicolumn{2}{|c|}{$\begin{array}{c}\text { Niethammer \& } \\
\text { Krapp 2001 }\end{array}$} & \multicolumn{2}{|c|}{ Benda et al 2003} & \multirow{2}{*}{$\begin{array}{c}\begin{array}{c}\text { Lanza 2012; Felter } \\
\text { et al } 1973\end{array} \\
\text { min - max }\end{array}$} \\
\hline & n. & $\min$ & $\max$ & mea & s.d. & $\mathrm{n}$. & $\min -\max$ & n. & $\min -\max$ & $\mathrm{n}$. & $\min -\max$ & \\
\hline \multicolumn{13}{|l|}{ Rhinolophus ferrumequinum } \\
\hline $\mathrm{C}-\mathrm{M} 3$ & 1 & & & 8,5 & & 3 & $8,4-8,6$ & 27 & $8,4-8,7$ & 93 & $8,31-9,08$ & $8,4-8,6$ \\
\hline M1-M3 & 2 & 5,1 & 5,2 & 5,15 & 0,071 & 6 & $4,9-5,3$ & & & & & \\
\hline L. mandible & 11 & 15,0 & 15,4 & 15,13 & 0,135 & 4 & $14,4-15,5$ & 27 & $14,9-15,9$ & 94 & $14,94-16,48$ & $15,0-16,3$ \\
\hline $\mathrm{c}-\mathrm{m} 3$ & 17 & 8,7 & 9,3 & 9,07 & 0,193 & 13 & $8,7-9,6$ & 27 & $9,0-9,3$ & 94 & $8,72-9,73$ & $8,8-9,3$ \\
\hline $\mathrm{m} 1-\mathrm{m} 3$ & 18 & 6,0 & 6,4 & 6,15 & 0,142 & 20 & $5,8-6,5$ & & & & & \\
\hline L. humerus & 10 & 32,4 & 35,0 & 33,74 & 1,075 & 2 & 33,2 & & & & & \\
\hline Bd humerus & 33 & 5,0 & 5,2 & 5,16 & 0,056 & 13 & $4,9-5,2$ & 27 & $4,8-5,3$ & & & $\sim 5,1$ \\
\hline \multicolumn{13}{|l|}{ Rhinolophus euryale } \\
\hline L. mandible & 1 & & & 11,4 & & 4 & $11,2-12,0$ & 29 & $11,5-12,2$ & 165 & $10,82-12,22$ & $11,5-12,2$ \\
\hline c-m3 & 2 & 6,4 & 6,8 & 6,60 & 0,283 & 14 & $6,2-7,0$ & 29 & $6,5-6,9$ & 168 & $5,91-6,92$ & $6,6-6,9$ \\
\hline $\mathrm{m} 1-\mathrm{m} 3$ & 2 & 4,2 & 4,6 & 4,40 & 0,283 & 22 & $4,2-4,7$ & & & & & \\
\hline L. humerus & 1 & & & 27,0 & & 10 & $25,9-28,2$ & & & & & \\
\hline Bd humerus & 1 & & & 4,3 & & 38 & $4,1-4,4$ & & & & & $\sim 4,3$ \\
\hline \multicolumn{13}{|l|}{ Rhinolophus mehelyi } \\
\hline Bd humerus & 1 & & & 4,6 & & 4 & $4,4-4,7$ & & & & & $\sim 4,5$ \\
\hline \multicolumn{13}{|l|}{ Rhinolophus hipposideros } \\
\hline L. skull & 1 & & & 15,3 & & & & 25 & $14,8-15,8$ & 45 & $15,25-16,76$ & $14,8-15,8$ \\
\hline $\mathrm{ZB}$ & 1 & & & 7,4 & & & & 25 & $7,0-7,8$ & 53 & $7,23-8,10$ & $7,3-7,8$ \\
\hline IcB & 1 & & & 1,6 & & & & 25 & $1,7-2,0$ & 62 & $1,38-2,00$ & $1,8-1,9$ \\
\hline $\mathrm{C}-\mathrm{C}$ & 1 & & & 3,2 & & & & 25 & & 58 & $2,98-3,88$ & \\
\hline M3-M3 & 1 & & & 5,3 & & & & 25 & & 62 & $4,93-5,64$ & \\
\hline $\mathrm{C}-\mathrm{M} 3$ & 2 & & & 5,4 & & & & 25 & $5,0-5,5$ & 61 & $5,08-5,53$ & $5,4-5,5$ \\
\hline M1-M3 & 2 & & & 3,4 & & & & & & & & \\
\hline L. humerus & 2 & 22,1 & 23,0 & 22,55 & 0,636 & 1 & 23,1 & & & & & \\
\hline Bd humerus & 4 & 3,0 & 3,1 & 3,05 & 0,058 & 4 & $3,0-3,3$ & & & & & $\sim 3,1$ \\
\hline
\end{tabular}

especially the barn owl, Tyto alba (Andrews 1990, Lanza 2012); the last two species are the main, if not the exclusive, agents of accumulation of the non-volant micromammal remains from some of the caves examined (Salari 2014). Bats can also be occasionally preyed on by diurnal birds of prey (Falconiformes), reptiles and amphibians, as well as some mammalian carnivores (domestic dogs and cats, mustelids and foxes) and infrequently by the edible dormouse, Glis glis (Agnelli \& Guaita 2009, Lanza 2012).

In the boluses or pellets of the Strigiformes, bats make rarely more than $1 \%$ of prey, as their regurgitations are mainly consist of rodents, small birds and soricomorphs (Sevilla 1988, Andrews 1990, Vernier 1993, Kowalski 1995, García et al. 2005). Among the material from these caves of Central Italy (leaving out the small sample from Grotta di Pastena), even where the number of remains is relatively low, percentages of bat individuals range from 11.5 to $40 \%$ of the micromammal total. These percentages can be correlated to anomalous behaviours of the predators or they can indicate autochthonous thanatocoenoses. In order to investigate what, and in which sites, were the agents of accumulation of the bat remains examined, taphonomic observations were undertaken following the methodologies proposed by Andrews (1990) and Fernández-Jalvo \& Andrews (1992). These include observations about the relative abundance of bones and their fragmentation, and analysis of the material for evidence of digestion and patterns leading to the identification of the possible predators.

Table 5 shows the different skeletal elements represented in the samples. Only in the sample from Grotta Regina
Margherita are almost all the skeletal elements represented. The humerus is the most abundant skeletal element from Grotta Bella, Grotta Mora Cavorso (burial area), Grotta di Pastena and Grotta Regina Margherita, whereas the most abundant elements from Grotta Continenza are the mandibles and from Grotta Mora Cavorso (Digs B, C and D) the radii (Table 5). The hindlimb bones and the smallest bones, such as phalanges, tarsal or metatarsal bones, together with isolated teeth, are absent or scarce in all the samples, especially when compared to the relative abundance of these elements expected for the respective estimated individuals (Table 5). Postcranial elements other than the humerus (not reported in Tables 1 and 2) are referable to the large-sized bats $(R$. ferrumequinum, M. myotis, M. blythii), except for two radii of medium-sized Rhinolophus and a radius referable to $M$. schreibersii from Grotta Continenza, and a radius of smallsized Myotis from Grotta Regina Margherita.

Skulls and skull fragments are missing or are very scarce in all the samples. Several maxillae were found, but only a sub-entire skull of $R$. hipposideros embedded in the stalagmite crust from Grotta Mora Cavorso (burial area), 4 splancnocrania of $M$. blythii from Grotta Continenza and a splancnocranium of M. myotis from Grotta Regina Margherita. Mandibles are more numerous, often with the ascending ramus missing. In all the samples, about half of the postcranial bones are intact, and recent breakage is observed in several bones (humerus, radius and metacarpal bones). However, it is difficult to estimate the extent to which the aforementioned absence and/or destructive processes are related to ingestion, digestion and deposition by possible predators or selection caused by water transport 
Table 4 - Vespertilionidae and Miniopteridae: osteometric measurements (mm). For abbreviations see Tab. 3 caption. By Rabeder (1972) only N. noctula measurements were taken; by Felten et al. (1973) only humerus measurements were taken. Of the data of M. blythii taken by Niethammer \& Krapp (2001), we have considered only M. blythii oxygnathus.

\begin{tabular}{|c|c|c|c|c|c|c|c|c|c|c|c|c|}
\hline \multirow{3}{*}{ Species/measurements } & \multicolumn{7}{|c|}{ early and middle Holocene bats of Italy } & \multicolumn{5}{|c|}{ European extant bats } \\
\hline & \multicolumn{5}{|c|}{$\begin{array}{c}\text { Five caves of Central Appennine (this } \\
\text { work) }\end{array}$} & \multicolumn{2}{|c|}{ Salari 2011} & \multicolumn{2}{|c|}{$\begin{array}{c}\text { Niethammer \& Krapp 2001; } \\
\text { Rabeder } 1972\end{array}$} & \multicolumn{2}{|c|}{ Benda et al 2003} & \multirow{2}{*}{$\begin{array}{c}\text { Lanza 2012; } \\
\text { Felten et al 1973 } \\
\min -\max \end{array}$} \\
\hline & n. & $\min$ & $\max$ & mea & s.d. & $\mathrm{n}$. & $\min -\max$ & $\mathrm{n}$. & $\min -\max$ & $\mathrm{n}$. & $\min -\max$ & \\
\hline \multicolumn{13}{|l|}{ Myotis myotis } \\
\hline $\mathrm{C}-\mathrm{C}$ & 1 & & & 6,2 & & 1 & 6,1 & 19 & $5,99-6,59$ & 71 & $5,35-6,55$ & \\
\hline M3-M3 & 1 & & & 10,0 & & 1 & 9,7 & & & 68 & $9,28-10,38$ & \\
\hline $\mathrm{C}-\mathrm{M} 3$ & 2 & & & 10,1 & & 2 & 9,8 & 20 & $9,65-10,24$ & 71 & $9,52-10,42$ & $9,8-10,0$ \\
\hline M1-M3 & 4 & 5,4 & 5,6 & 5,55 & 0,100 & 2 & 5,6 & & & & & \\
\hline L. mandible & 1 & & & 17,6 & & 2 & 17,4 & 20 & $17,79-19,14$ & 72 & $17,32-18,87$ & $17,5-18,0$ \\
\hline $\mathrm{c}-\mathrm{m} 3$ & 1 & & & 11,4 & & 5 & $10,5-11,1$ & 20 & $10,15-11,11$ & 72 & $10,33-11,90$ & $10,5-10,8$ \\
\hline m1-m3 & 2 & & & 6,8 & & 7 & $6,2-6,6$ & & & & & \\
\hline L. humerus & 2 & 33,3 & 33,8 & 33,55 & 0,354 & 4 & $34,2-34,6$ & & & & & \\
\hline Bd humerus & 2 & 4,3 & 4,4 & 4,35 & 0,071 & 15 & $4,4-4,6$ & & & & & $4,0-4,6$ \\
\hline \multicolumn{13}{|l|}{ Myotis blythii } \\
\hline $\mathrm{C}-\mathrm{C}$ & 4 & 5,8 & 6,1 & 5,95 & 0,173 & 1 & 6,2 & 19 & $5,36-5,89$ & 37 & $5,22-6,17$ & \\
\hline M3-M3 & 4 & 8,6 & 9,2 & 8,90 & 0,346 & 2 & 9,2 & 19 & $8,41-9,13$ & 36 & $8,05-9,27$ & \\
\hline C-M3 & 8 & 8,8 & 9,2 & 8,97 & 0,138 & 3 & $8,9-9,2$ & 19 & $8,21-9,03$ & 38 & $8,06-9,13$ & $8,6-8,8$ \\
\hline M1-M3 & 10 & 5,0 & 5,2 & 5,16 & 0,088 & 6 & $5,0-5,4$ & 19 & $4,82-5,29$ & & & \\
\hline $\mathrm{c}-\mathrm{m} 3$ & 20 & 9,2 & 10,2 & 9,55 & 0,260 & 21 & $9,8-10,2$ & 19 & $8,83-9,68$ & 39 & $8,85-9,80$ & $9,0-9,5$ \\
\hline m1-m3 & 28 & 5,4 & 6,1 & 5,84 & 0,221 & 32 & $5,4-6,1$ & 19 & $5,26-5,86$ & & & \\
\hline L. humerus & 5 & 31,6 & 32,6 & 32,16 & 0,434 & 12 & $31,9-32,4$ & & & & & \\
\hline Bd humerus & 13 & 4,0 & 4,2 & 4,13 & 0,095 & 36 & $3,9-4,3$ & & & & & $4,0-4,6$ \\
\hline \multicolumn{13}{|l|}{ Myotis bechsteini } \\
\hline L. humerus & 2 & & & 24,0 & & & & & & & & \\
\hline $\mathrm{Bd}$ humerus & 4 & & & 3,0 & & & & & & & & $2,9-3,1$ \\
\hline \multicolumn{13}{|l|}{ Myotis capaccinii } \\
\hline $\mathrm{C}-\mathrm{M} 3$ & 2 & & & 5,8 & & & & 28 & $5,2-5,8$ & 29 & $5,35-5,91$ & $5,4-6,0$ \\
\hline M1-M3 & 2 & & & 3,0 & & & & & & & & \\
\hline L. mandible & 7 & 10,4 & 11,2 & 10,80 & 0,383 & & & 28 & $10,0-11,7$ & 28 & $10,38-11,38$ & $10,4-11,7$ \\
\hline $\mathrm{c}-\mathrm{m} 3$ & 12 & 5,8 & 6,2 & 6,10 & 0,135 & 1 & 6,2 & 28 & $5,7-6,4$ & 28 & $5,69-6,53$ & $5,7-7,0$ \\
\hline $\mathrm{m} 1-\mathrm{m} 3$ & 13 & 3,8 & 4,0 & 3,83 & 0,075 & 1 & 3,7 & & & & & \\
\hline L. humerus & 3 & 21,2 & 22,0 & 21,73 & 0,462 & 2 & 23,5 & & & & & \\
\hline Bd humerus & 14 & 2,7 & 3,0 & 2,79 & 0,077 & 11 & $2,7-3,0$ & & & & & $\sim 2,7$ \\
\hline \multicolumn{13}{|l|}{ Myotis emarginatus } \\
\hline L. humerus & 1 & & & 22,2 & & & & & & & & \\
\hline \multicolumn{13}{|l|}{ Hypsugo vel Pipistrellus } \\
\hline L. humerus & 1 & & & 22,8 & & & & & & & & \\
\hline Bd humerus & 1 & & & 2,4 & & & & & & & & $2,2-2,4$ \\
\hline Nyctalus noctula & & & & & & & & & & & & \\
\hline $\mathrm{c}-\mathrm{m} 3$ & 1 & & & 7,5 & & & & & 7,6 & 12 & $7,53-8,17$ & $7,2-8,29$ \\
\hline m1-m3 & 1 & & & 5,2 & & & & & 5,3 & & & \\
\hline Plecotus auritus s.l. & & & & & & & & & & & & \\
\hline L. humerus & 1 & & & 23,8 & & & & & & & & \\
\hline Bd humerus & 1 & & & 2,8 & & 1 & 2,8 & & & & & $2,7-2,9$ \\
\hline Barbastella barbastellus & & & & & & & & & & & & \\
\hline Bd humerus & 2 & 2,7 & 2,8 & 2,75 & 0,071 & & & & & & & $2,7-2,8$ \\
\hline Miniopterus schreibersii & & & & & & & & & & & & \\
\hline L. mandible & 1 & & & 10,8 & & 3 & $10,9-11,2$ & & & 66 & $10,41-11,08$ & $10,7-10,9$ \\
\hline $\mathrm{c}-\mathrm{m} 3$ & 1 & & & 6,2 & & 4 & $6,2-6,4$ & & & 66 & $6,13-6,48$ & $6,3-6,4$ \\
\hline m1-m3 & 1 & & & 3,6 & & 5 & $3,6-3,9$ & & & & & \\
\hline L. humerus & 4 & 24,6 & 26,0 & 25,40 & 0,632 & 11 & $25,2-26,4$ & & & & & \\
\hline Bd humerus & 8 & 2,7 & 2,8 & 2,78 & 0,046 & 21 & $2,6-2,8$ & & & & & $\sim 2,7$ \\
\hline
\end{tabular}

or to destructive post-depositional processes. In the caves occupied by humans, trampling can also be responsible for dispersal, breakage and burial of bones (Andrews 1990). The weight of the sediments and the continuous trampling in confined spaces can cause bone fragmentation and the smaller fragments (together with isolated teeth and smaller bones) can be overlooked during collection. In the sites where it was used, the large mesh $(2 \mathrm{~mm})$ for sieving is most likely a cause of such loss. This has not strongly affected the intact long bones, the fragments of larger size, skull fragments, maxillae and mandibles, because their shape and size makes them more easily retained in the mesh.
Ascertained traces of digestion were found only on two distal epiphyses of humerus from Grotta di Pastena, but the material is too poor to identify the probable predator. Therefore it is very likely that the finds from the other caves consisted mainly of the natural accumulation of animals that lived and died there. The taxa identified were mostly troglophilous species in all the sites, whereas species that usually roost in hollow trees, or rock crevices, as well as those today distinctly anthropophilous, were lacking or missing. These data suggest that the non-troglophilous species may really be underrepresented, but they tend to confirm that the vast majority of the bat remains examined (except for Pastena) represent autochthonous thanatocoenoses (Sevilla 1988, Kowalski 1995, López-García \& Sevilla 2012). 
Table 5 - Skeletal elements represented in the bat assemblages. The percentage is calculated versus the theoretical frequency of the anatomical element considered ( 2 maxillae, 2 mandibles, 2 scapulae, 2 humeri, 2 radii, 2 ulnas, 10 metacarpal bones, 2 pelves, 2 femora, 2 tibias, 2 astragals, 2 calcanei, 10 metatarsal bones and 56 phalanges); each skull or splanchnocranium was counted as 2 maxillae. For abbreviations see Tab. 1 caption.

\begin{tabular}{|c|c|c|c|c|c|c|c|c|c|c|c|c|c|c|}
\hline \multirow{3}{*}{ Skeletal elements } & $\mathrm{GC}$ & $\mathrm{GC}$ & $\mathrm{GC}$ & $\mathrm{GC}$ & $\overline{\text { GMC }}$ & GMC & GMC & GMC & GB & GB & GRM & GRM & $\mathrm{GP}$ & $\mathrm{GP}$ \\
\hline & M & $\mathrm{M}$ & $\mathrm{N}$ & $\mathrm{N}$ & $\mathrm{N}$ & $\mathrm{N}$ & NB & NB & B & B & B & B & B & B \\
\hline & n. & $\%$ & $\mathrm{n}$. & $\%$ & n. & $\%$ & n. & $\%$ & n. & $\%$ & $\mathrm{n}$. & $\%$ & n. & $\%$ \\
\hline Maxilla & 6 & & 12 & 31,6 & 2 & 25,0 & & & & & 6 & 13,6 & & \\
\hline Mandible & 40 & 48,8 & 22 & 57,9 & 1 & 12,5 & 1 & 5,0 & & & 17 & 38,6 & & \\
\hline Scapula & & & & & & & & & & & 2 & 4,5 & & \\
\hline Humerus & 39 & 47,6 & 16 & 42,1 & 5 & 62,5 & 15 & 75,0 & 11 & 91,7 & 22 & 50,0 & 3 & 75,0 \\
\hline Radius & 3 & 3,7 & 6 & 15,8 & & & 18 & 90,0 & 8 & 66,7 & 16 & 36,4 & 3 & 75,0 \\
\hline \multicolumn{15}{|l|}{ Ulna } \\
\hline \multicolumn{15}{|l|}{ Carpal bones } \\
\hline Metacarpal bones & 5 & 1,2 & 5 & 2,6 & & & 8 & 8,0 & 4 & 6,7 & 36 & 16,4 & 14 & 70,0 \\
\hline Pelvis & & & & & & & & & & & 1 & 2,3 & & \\
\hline Femur & & & & & & & 2 & 10,0 & 3 & 25,0 & 4 & 9,1 & 3 & 75,0 \\
\hline Tibia & & & & & & & & & & & 2 & 4,5 & & \\
\hline \multicolumn{15}{|l|}{ Tarsal bones } \\
\hline \multicolumn{15}{|l|}{ Metatarsal bones } \\
\hline Phalanges & & & & & & & 7 & 1,3 & 1 & 0,3 & 14 & 1,1 & 7 & 6,3 \\
\hline MNI & 41 & & 19 & & 4 & & 10 & & 6 & & 22 & & 2 & \\
\hline
\end{tabular}

Table 6 - Comparison between early and middle Holocene bats (data from Taliana et al. 1996, Wilkens 1996, Salari \& Di Canzio 2009, Salari 2011, and this work) and the current bat fauna from Umbria, Abruzzi and Latium (data from Agnelli et al. 2006, Russo et al. 2010, Biscardi et al. 2012), and schematic synthesis of some ecological attributes of the bats (Horáček et al. 2000, Lanza \& Agnelli 2002, Agnelli et al. 2006, Salari \& Di Canzio 2009, Lanza 2012). e.m.H.: early and middle Holocene; s.s.: sensu stricto; s.1.: sensu lato.

\begin{tabular}{|c|c|c|c|c|c|c|}
\hline \multirow[t]{2}{*}{ Species } & \multicolumn{2}{|c|}{$\begin{array}{c}\text { Umbria, Abruzzi } \\
\text { and Latium }\end{array}$} & \multirow{2}{*}{ hibernacula } & \multirow{2}{*}{$\begin{array}{c}\text { temperatures } \\
\text { of } \\
\text { hibernation }\end{array}$} & \multirow{2}{*}{$\begin{array}{c}\text { foraging } \\
\text { environment }\end{array}$} & \multirow{2}{*}{$\begin{array}{c}\text { zoogeographical } \\
\text { patterns }\end{array}$} \\
\hline & e.m.H. & today & & & & \\
\hline Rhinolophus ferrumequinum & $\mathrm{X}$ & $\mathrm{X}$ & caves & 7 to $12{ }^{\circ} \mathrm{C}$ & mixed & Mediterranean s.1. \\
\hline Rhinolophus euryale & $\mathrm{X}$ & $X$ & caves & 10 to $12^{\circ} \mathrm{C}$ & woods & Mediterranean s.s. \\
\hline Rhinolophus mehelyi & $X$ & & caves & 11 to $13^{\circ} \mathrm{C}$ & woods & Mediterranean s.s. \\
\hline Rhinolophus hipposideros & $\mathrm{X}$ & $X$ & caves & 4 to $12^{\circ} \mathrm{C}$ & woods & Mediterranean s.l. \\
\hline Myotis myotis & $\mathrm{X}$ & $X$ & caves & 2 to $12^{\circ} \mathrm{C}$ & woods & Mediterranean s.l. \\
\hline Myotis bechsteini & $X$ & $X$ & hollow trees, caves & 1 to $10^{\circ} \mathrm{C}$ & woods & Nemoral \\
\hline Myotis capaccinii & $\mathrm{X}$ & $X$ & caves & 4 to $15^{\circ} \mathrm{C}$ & woods & Mediterranean s.s. \\
\hline Myotis daubentoni & $?$ & $\mathrm{X}$ & caves & 0 to $10^{\circ} \mathrm{C}$ & forests & Boreal \\
\hline Myotis emarginatus & $X$ & $X$ & caves & 5 to $9^{\circ} \mathrm{C}$ & various & mediterranea s.l. \\
\hline Myotis nattereri & $?$ & $X$ & caves & 2 to $8^{\circ} \mathrm{C}$ & woods & Nemoral \\
\hline Myotis mystacinus & $X ?$ & $\mathrm{X}$ & caves & 2 to $8^{\circ} \mathrm{C}$ & various & Nemoral \\
\hline Myotis alcathoe & $?$ & $X$ & caves & $?$ & forests & Nemoral? \\
\hline Pipistrellus kuhlii & $?$ & $\mathrm{X}$ & building, rock fissures & $?$ & $\begin{array}{c}\text { various, } \\
\text { anthropophilous }\end{array}$ & Mediterranean s.s. \\
\hline Pipistrellus nathusii & $?$ & $\mathrm{X}$ & rock fissures, building & $?$ & woods & Nemoral \\
\hline Pipistrellus pipistrellus s.l. & & $\mathrm{X}$ & building, hollow trees & 0 to $6^{\circ} \mathrm{C}$ & $\begin{array}{l}\text { woods, } \\
\text { anthropophilous }\end{array}$ & Mediterranean s.l. \\
\hline Hypsugo savii & $?$ & $\mathrm{X}$ & building, caves & $\sim 12{ }^{\circ} \mathrm{C}$ & $\begin{array}{c}\text { various, } \\
\text { anthropophilous }\end{array}$ & Mediterranean s.s. \\
\hline Eptesicus serotinus & & $X$ & building, caves & 2 to $4^{\circ} \mathrm{C}$ & various & Mediterranean s.l. \\
\hline Nyctalus leisleri & & $X$ & hollow trees & $?$ & woods & Nemoral \\
\hline Nyctalus noctula & $X$ & $\mathrm{X}$ & hollow trees & $>-7^{\circ} \mathrm{C}$ & forests & Nemoral \\
\hline Barbastella barbastellus & $x$ & $X$ & caves & 0 to $8^{\circ} \mathrm{C}$ & forests & Nemoral \\
\hline Plecotus auritus & $X ?$ & $\mathrm{X}$ & hollow trees, caves & 2 to $5^{\circ} \mathrm{C}$ & forests & Boreal \\
\hline Plecotus austriacus & & $X$ & grotte, hollow trees & 2 to $12^{\circ} \mathrm{C}$ & woods & Mediterranean s.l. \\
\hline Miniopterus schreibersii & $X$ & $\mathrm{X}$ & caves & 4 to $12^{\circ} \mathrm{C}$ & various & Mediterranean s.s. \\
\hline
\end{tabular}


Elements of juvenile bats were not identified in any sample, whereas in Grotta Bella, Grotta Mora Cavorso and Grotta Regina Margherita juvenile remains of Glis glis, Apodemus sylvaticus vel flavicollis and other rodents were found (Salari 2014, in press), along with perinatal remains of domestic animals from Grotta Continenza and Grotta Mora Cavorso (Barra et al. 1990, Salari et al. 2012, Silvestri et al. in press). This suggests that the absence of juvenile bat remains is not simply attributable to processes of differential destruction, and therefore we hypothesize that the examined remains were accumulated mainly during hibernation, during the winter semester.

\section{MicROCLIMATEANDENVIRONMENT}

For bats, the choice of diurnal roosts, as well as of reproduction and hibernation environments, is strongly influenced by the microclimate of the cave. Every species has a specific level of tolerance to limited ranges of temperature and humidity (generally, low temperature with high hygrometric rate) (Niethammer \& Krapp 2001, Lanza \& Agnelli 2002, Lanza 2012). However, temperature and humidity in caves can vary according to cave size, its morphology, the number of openings and their orientation. Larger caves can have different microclimates (with more or less constant temperatures but variable humidity, owing above all to draughts of air) and each species selects the spots that best suit their preferences (Sevilla 1988, Lanza \& Agnelli 2002, Lanza 2012).

With the only exception of Pastena, taphonomical observations suggest that the remains examined accumulated prevalently during the winter semester. By evaluating the hibernation requirements of the taxa identified (Table 6), inferences can be drawn about the winter microclimate of the caves (at least related to the areas close to the excavation areas) in the time intervals considered.

At Grotta Mora Cavorso, in the inner chambers that held the human remains of at least 21 individuals, the Neolithic's microclimate was probably characterised by a high humidity (close to saturation) and a temperature ranging between 7 and $12^{\circ} \mathrm{C}$. The hypothesis, already formulated by Salari \& Kotsakis (2011), has recently been confirmed by both the study of the stalagmite formations and the monitoring of the current physical parameters of the karst cave. In fact, in the winter semester of 2007-2008, temperatures between 10 and $12{ }^{\circ} \mathrm{C}$ were recorded, with a relative humidity close to $80 \%$ in the inner chambers of the cave (Rolfo et al. 2012c). The temperature values, estimated on the basis of the assumed needs of the identified taxa, are thus compliant with the physical parameters recorded. With regards to the humidity, instead, it has to be noted that calcite precipitation in the Neolithic required a higher hygrometric rate than at present (Rolfo et al. 2012b).

Supported by these experimental results, we can hypothesize that in the chronological intervals considered, at Grotta Continenza the winter microclimate remained rather constant, with average temperatures ranging from 8 to $12^{\circ} \mathrm{C}$ and a high humidity; moreover, we can assume that the winter temperature ranged between 4 and $12^{\circ} \mathrm{C}$ in Grotta Bella, and between 10 and $12^{\circ} \mathrm{C}$ in Grotta Regina Margherita. The occurrence of some taxa that usually roost in hollow trees (Nyctalus noctula, Plecotus auritus s.l.), in addition, might indicate periods of climatic deterioration or at least particularly cold winters.

Bats have a foraging range of several kilometres from their roosts (Niethammer \& Krapp 2001, Lanza \& Agnelli 2002, Lanza 2012). Therefore, by analysing the actual distribution areas and foraging environments of the taxa identified (Table 6), the study of the bones found in the archaeological digs provides interesting information on the surroundings of the caves at the time of their deposition.

For refined quantitative analyses, significantly numerous samples are required, taking into account that some species form large colonies (monospecific or mixed), even of thousands of individuals (e.g., Myotis myotis, M. blythii, M. capaccinii, Miniopterus schreibersii), others form smaller colonies, from a few individuals to several hundred (e.g., Rhinolophus ferrumequinum, $R$. hipposideros, M. mystacinus) or have more solitary behaviours (e.g., M. bechsteini, M. emarginatus, Barbastella barbastellus). However, despite the limited numerical significance of some samples, these can still provide useful environmental information.

For example, species found at Grotta Bella suggest that, in the Bronze Age, the slopes of Mount Aiola were mostly covered by woodland near wetland areas and they were frequented by Myotis bechsteinii and M. capaccinii, whereas the presence of Miniopterus schreibersii indicates the existence of a more varied environment, both rich in woodlands and clearings. The bat taxa found at Grotta Mora Cavorso show that in the chronological interval considered in the Upper Aniene Valley both woodlands, frequented by Myotis myotis, Plecotus auritus s.l. and Rhinolophus hipposideros, and open spaces were present, as suggested by Myotis blythii, which prefers rich grasslands as foraging areas, avoiding both arid or denuded areas and any type of woodland and forest. At the same time, $R$. ferrumequinum indicates the presence of different environments, both forested and open, close to waterways. Although the individuals of the species that prefer mixed environments are relatively numerous (R. ferrumequinum, Myotis mystacinus s.l. and Miniopterus schreibersii), the surroundings of the Grotta Regina Margherita, in Collepardo, were likely to be covered by woodlands in the Middle Bronze Age, and frequented by the other rhinolophids and by M. myotis, whereas the presence of $M$. blythii indicates the existence also of open spaces (Fig. 2).

The ratio of the taxa recovered from the stratigraphic sequence of Grotta Continenza, finally, shows that from the Mesolithic (layer 27) to the Neolithic (layer 23), along the Fucino basin and the slopes of Mount Labbrone, the tree crown cover increased at the expense of open spaces (Fig. 3). In effect, this coincides with an increase in the woodlandadapted species, with some fluctuations, from 36.4 to $55.6 \%$.

The aforementioned environmental indications provided by bats are generally compliant with those derived from the study of the non-volant micromammals, i.e. rodents and soricomorphs (Di Canzio 2004, Salari 2014). 


\section{BIOGEOGRAPHY}

All the taxa identified are still part of the extant Italian bat fauna. With regards to the species recognised through the use of modern bioacustic and biomolecular analyses (see "Systematic notes"), in Italy P. pygmaeus seems to be found along the entire pensinsula, M. punicus and $P$. sardus in Sardinia, M. alcathoe in central and southern Italy, $P$. macrobullaris in the Alpine regions, $P$. kolombatovici in the extreme North-East, P. gaisleri in the island of Pantelleria, whereas the presence of $M$. aurescens has not been confirmed (Agnelli et al. 2006, Lanza 2012).

The taxa identified are mainly species of Mediterranean affinities (sensu lato and sensu stricto, Horáček et al. 2000), both in terms of the number of identified remains and invididuals and the number of sites where they were found. The presence of nemoral and especially boreal species is not significant (Table 6), which is similar to the trend on the peninsula for the extant bat fauna (Lanza \& Agnelli 2002, Salari \& Di Canzio 2009).

Comparing the taxa identified only with those present today in the caves examined or their surroundings might be misleading, although in some cases this could provide data about the stability of the roost choices of those species. By widening the comparisons to species that live in Umbria, Latium and Abruzzi today (Agnelli et al. 2006, Russo et al. 2010, Biscardi et al. 2012), integrating the data discussed so far with the literature of the bat remains from Grotta del Lago, Grotta Sant'Angelo and Grotta dei Cocci (Taliana et

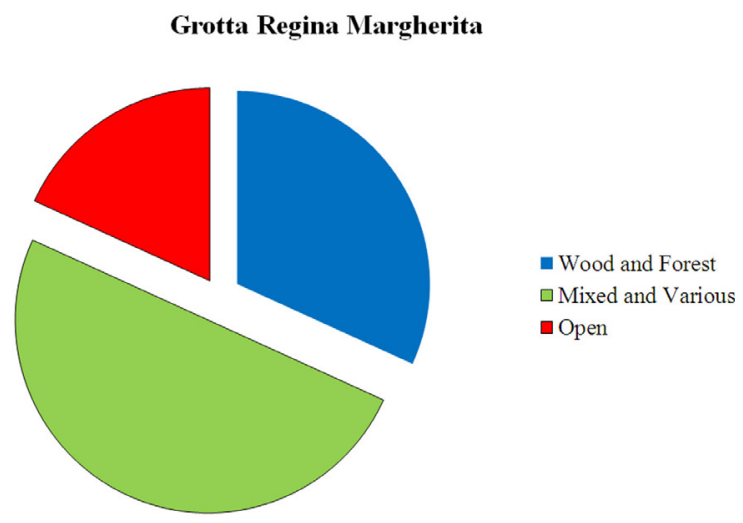

Fig. 2 - Grotta Regina Margherita, Bronze Age, Chiroptera: percent ratio (number of individuals) according to foraging environment (see Tab. 6).

al. 1996, Wilkens 1996, Salari \& Di Canzio 2009, Salari 2011), it can be noted instead that the bat fauna of these regions in the early and middle Holocene was already very similar to the present (Table 6). Regional peculiarities can be also noted, such as the presence of Myotis capaccinii and Rhinolophus euryale in Abruzzi, a region where they are not recorded after 1980 (Agnelli et al. 2006). The key presence to be considered in this framework, however, is that of Rhinolophus mehelyi, a species that now does not live in the area, at Grotta Continenza and Grotta dei Cocci in the early and middle Holocene.

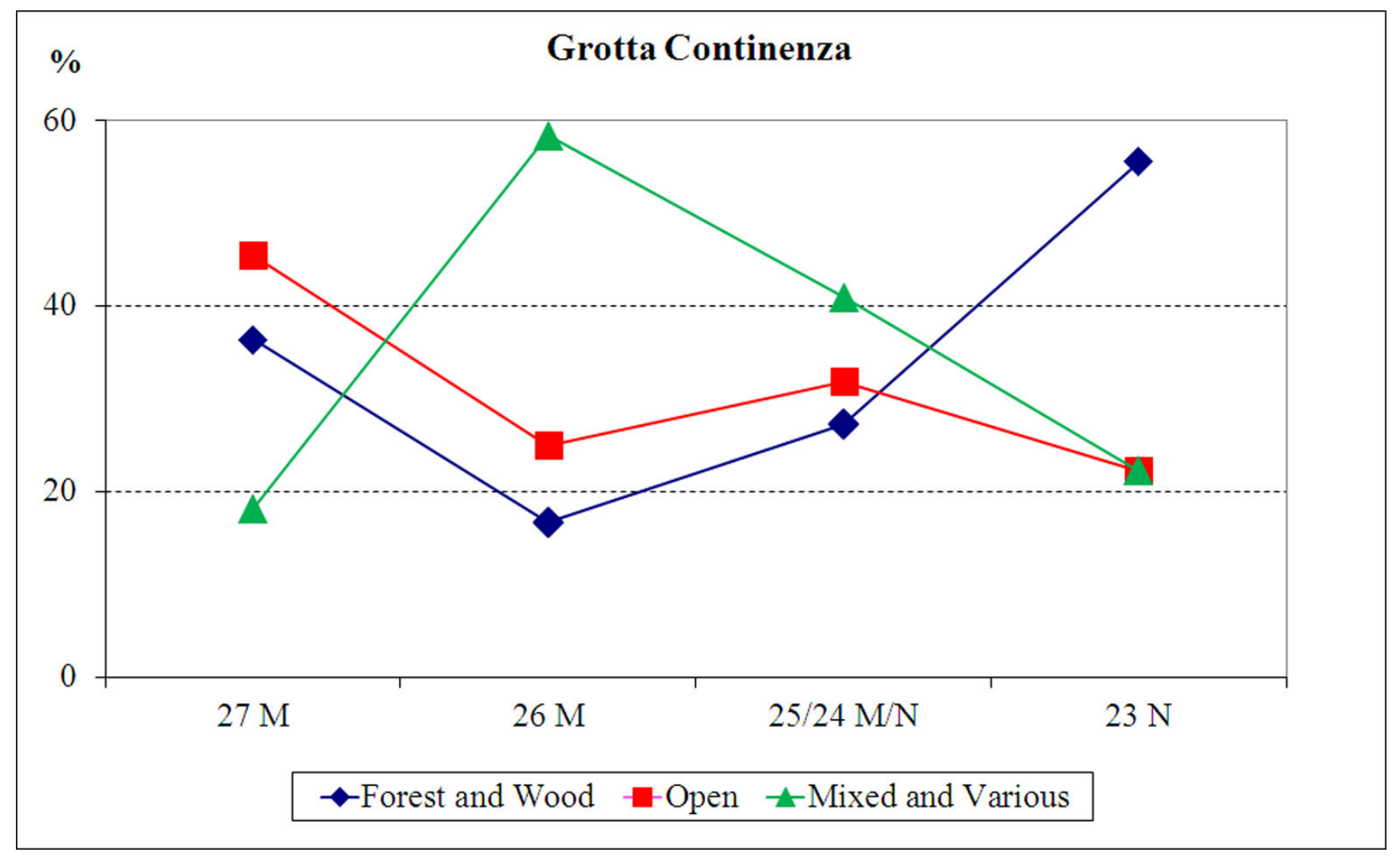

Fig. 3 - Grotta Continenza, Mesolithic and Neolithic, Chiroptera: percent ratio (number of individuals) between layer 27 and layer 23 according to foraging environment (see Tab. 6). M: Mesolithic; N: Neolithic. 
$R$. mehelyi is a cave-dwelling bat particularly sensitive to human disturbance, and in Italy presently limited in its distribution to Sardinia and Sicily, and probably Apulia (Agnelli et al. 2006, Mucedda et al. 2009, Lanza 2012, Dondini et al. 2014). Before 1980, the only ascertained occurrences in the peninsula were restricted to Apulia (Grotta della Cava, Grotte di Castellana and Grotta Zinzulusa, these latter open to tourism), whereas the past and the recent records in Calabria and Campania have been subsequently not confirmed (Mucedda et al. 2009, Lanza 2012). In the entire range of its distribution, $R$. mehelyi is today considered vulnerable and endangered: it has declined in numbers in the Iberian peninsula, where it is relatively more abundant, close to extinction in France and perhaps already extinct in Corsica, Croatia and Israel (Agnelli et al. 2006, Mucedda et al. 2009, Lanza 2012), but after about 45 years it has reappeared in Apulia, at Grotta Zinzulusa (Dondini et al. 2014). In the Lateglacial, Mehely's horseshoe bat is reported in few sites of Mediterranean Europe and Caucasus; in Italy it occurs both in the Northern (Caverna delle Arene Candide, Isola di Palmaria, Grotta del Broion) and in the Central-Southern part of the Peninsula (Grotta Continenza, Grotta Paglicci) (Salari \& Di Canzio 2009, Salari 2010, 2011, 2012) and in the less recent Holocene in Grotta Continenza and Grotta dei Cocci. Given that this species is linked to a certain extent to forested areas, these records might indicate a reduction of an initially wider range caused by the reduction of woodland (for natural or human causes) in a large portion of the Italian territory during the Holocene.

\section{Human aCtivity}

With regards to the human-bats interaction, it is known that chiropterans generally avoid caves that are intensively frequented by humans (Guillem Calatayud 1997, Rossina 2006, Rossina et al. 2006, Salari \& Kotsakis 2011, LópezGarcía \& Sevilla 2012). In addition, there is no evidence that they were preyed on by prehistoric hunters for food or other purposes in Europe, whereas exceptions in other parts of the world have been recorded (e. g., Hand \& GrantMackie 2012). Bats can be occasional targets by birds of prey (see "Taphonomic observations"), which do not usually frequent caves that are regularly occupied by humans. Therefore, the bones examined are likely to testify to periods of abandonment or sporadic frequentation by humans. It has been well documented that the number of bat remains is generally inversely proportional, if not specular, to the quantity of lithic finds and/or anthropogenic traces found on animal bones (Jullien 1972, Salari 2010, 2012, Salari \& Kotsakis 2011). A considerable presence of bats, in addition, can provide indirect data also on the seasonality of human frequentation, along with other indicators such as the presence or absence of juveniles among the most commonly hunted species in prehistory.

Taking into account that the time intervals studied might have been unequal and that environmental factors might also have been influential, the decrease in remains from the Mesolithic to the Neolithic at Grotta Continenza (Tables 1 and 2) suggests progressive intensification of human frequentation of the cave. The alternating frequentation of the cave by bats and humans might be pluriannual or even seasonal (late spring - early autumn for humans, late autumn
- early spring for bats). With regards to the Neolithic, the second scenario would be supported by the funerary and/or ritual use of the cave in this period (Barra et al. 1990).

With regards to the caves of Latium, archaeological and zooarchaeological studies are still ongoing, but it might not be the case that, at Grotta di Pastena, the only bat remains found were located in the niche "E10", next to the lowest quantity of faunal remains presumably brought into the cave by humans (a fragment of juvenile radius of Ovis vel Capra) (Angle et al. 2010a). At Grotta Regina Margherita, the majority $(68.6 \%)$ of the bat remains are from Dig C (1 sq $\mathrm{m}$ ); the other finds are equally divided between Dig A (8 sq $\mathrm{m}$ ) and Dig D (9 sq m), whereas Dig B (3 sq m) and Dig E (1 sq m) did not hold any (Angle et al. 2010b). Therefore, a small portion of the sediment deposited in a roughly equal time period produced a higher number of finds. Still keeping in mind that such an unequal distribution of bat osteological remains might be connected to microclimatic factors and preferences in the selection of roosts, it is plausible that human disturbance (smoke from hearths, light and noise) of the bats was lower in the area of Dig C compared to elsewhere in the cave.

\section{Conclusions}

This study documents the presence of bats in five caves of Central Italy (Umbria, Lazio, Abruzzi) in the early and middle Holocene (between the Mesolithic and the Bronze Age, i.e. between the Preboreal and the Subboreal chronozones). Sixteen taxa have been identified, subdivided into three families (Rhinolophidae, Vespertilionidae and Miniopteridae) and seven genera (Rhinolophus, Myotis, Nyctalus, Plecotus, Barbastella, Miniopterus and Hypsugo vel Pipistrellus). The remains examined are morphologically and morphometrically indistinguishable from the extant species.

The taphonomical observations suggest that the bat assemblages examined are autochthonous thanatocoenoses, except for that from Grotta di Pastena, which may have been accumulated by a predator. It has been briefly shown how the relative abundance of bat remains in the sediments can reveal periods of absence or occasional frequentation of the caves by prehistoric humans. Analysis of their ecological attributes has allowed formulation of some hypotheses on the winter microclimate of the caves, as well as on the environments surrounding the various sites. The estimated microclimate for the inner chambers of Grotta Mora Cavorso has been supported by study of the speleothems and monitoring of the current physical parameters (temperature, relative humidity) of the karst cave. The environmental indications provided by bats are generally compliant with those derived from the study of other microvertebrates, rodents and soricomorphs in particular.

The comparison between the taxa identified in the caves examined, integrated with published data, and those taxa still found in Umbria, Latium and Abruzzi, sheds new light on the dynamics of bat populations between the end of the Pleistocene and the present-day in these regions. In the latest phases of the Pleistocene (Last Glacial Maximum and Lateglacial), some boreal species were present in Central Italy, such as Myotis dasycneme and Eptesicus nilssonii, 
alongside various taxa of Mediterranean affinities (Salari \& Di Canzio 2009, Salari \& Kotsakis 2011). In the initial phases of the Holocene, the global warming that pushed the "cold" species North to their original distribution range has clearly favoured a similar trend of the bat fauna population as today, also in the innermost areas of the Apennines.

Finally, the occurrence of Rhinolophus mehelyi in the Central Apennines during the early and middle Holocene provides new information on the past geographical distribution of this species, which today occurs only in Sicily and Sardinia and which has been recently re-discovered in Apulia.

\section{ACKNOWLEDGEMENTS}

We are grateful to Katia F. Achino and Tassos Kotsakis for their support. We thank also Suzanne Hand, Juan Manuel López and a third anonymous referee for insightful suggestions on an earlier draft of the manuscript.

\section{REFERENCES}

Agnelli, P. \& Guaita, C. 2009. Predazione di Glis glis su una colonia di Myotis emarginatus nella Riserva Naturale di Ponte Buriano e Penna (AR). In: G. Dondini, G. Fusco, A. Martinoli, M. Mucedda, D. Russo, M. Scotti, S. Vergari (eds.), Chirotteri italiani: stato delle conoscenze e problemi di conservazione - Atti del $2^{\circ}$ Convegno Italiano sui Chirotteri, pp. 69-71.

Agnelli, P., Martinoli, A., Patriarca, E., Russo, D., ScARAVELli, D. \& GeNOVESI, P. 2006. Guidelines for bat monitoring: methods for the study and conservation of bats in Italy. Quaderni di Conservazione della Natura, 19 bis, Min.Ambiente - Ist. Naz. Fauna Selvatica, 200 pp.

Andrews, P. 1990. Owls, cave and fossils: Predation, preservation, and accumulation of small mammal bones in caves, with an analysis of the Pleistocene cave faunas from

Westbury-sub-Mendip, Somerset, UK. Natural History Museum Publications, London, 231 pp.

Angle, M., Bruni, N., Cerqua, M., Riva, A., Cavazzuti, C. \& Celletti, P. 2010a. Nuovi scavi nella grotta di Pastena (Frosinone). Lazio e Sabina 6: 369-380.

Angle, M., Catracchia, C., Cavazzuti, C., Celletti, P., Malorgio, M. \& Mancini, D. 2010b. La grotta Regina Margherita a Collepardo (Frosinone). Lazio e Sabina 6: 381-393.

Angle, M., Rolfo, M.F., Fusco, I. \& Silvestri, L. 2014. New investigations at the Cave of Pastena (Frosinone). Report 2012. Lazio e Sabina 10: 205-2011.

Barra, A., Grifoni Cremonesi, R., Mallegni, F., Piancastelli, M., Vitello, A. \& Wilkens, B. 1990. La Grotta Continenza di Trasacco. I livelli a ceramiche. Rivista Scienze Preistoriche 42: 31-100.
Benda, P., IVAnova, T., HoráČeK, I., HanÁK, V., ČERVEnÝ, J., Gaisler, J., Gueorguieva,A., Petrov,A., \& Vohralík, V. 2003. Bats (Mammalia: Chiroptera) of the Eastern Mediterranean. Part 3. Review of bat distribution in Bulgaria. Acta Societatis Zoologicae Bohemicae 67: 245-357.

Bevilacqua, R. 1994. La Grotta Continenza di Trasacco. I livelli mesolitici ed epigravettiani. Rivista Scienze Preistoriche 46: 3-39.

Biscardi, S., Cistrone, L., Tomassini, A., Pieroni, A. \& Russo, D. 2012. I chirotteri della Riserva Naturale Regionale Monti Navegna e Cervia. ARP, Roma, 84 pp.

Csorba, G., Ujhelyi, P. \& Thomas, N. 2003. Horseshoe Bats of the World (Chiroptera: Rhinolophidae). Alana Book, Bishop's Castle, 160 pp.

Curci, A., De Angelis, M.C., Moroni, A., Padoanello, S. \& Tagliacozzo, A. 2014. Grotta Bella (Umbria). Dati per un'analisi economica e paleo ambientale. Rivista Studi Liguri 77/79 (2011/13): 143-150.

Curci, A., Padoanello, S. \& Tagliacozzo, A. 2010. Nuove analisi archeozoologiche a Grotta Bella (Terni): considerazioni economiche e paleoambientali. In: A. Tagliacozzo, I. Fiore, S. Marconi, U. Tecchiati (eds.), Atti del $5^{\circ}$ Convegno Nazionale di Archeozoologia, Osiride, Rovereto, pp. 135-138.

Di CAnzio, E. 2004. Record a micromammiferi dell'area mediterranea e loro relazioni con la ciclicità climatica ad alta frequenza dell'ultimo glaciale. $\mathrm{PhD}$ Thesis in Paleontological Sciences, Modena, Bologna andRoma "Sapienza" Universities.

Dondini, G., Tomassini, A., Inguscio, S. \& Rossi, E. 2014. Rediscovery of Mehely's horseshoe bat (Rhinolophus mehelyi) in peninsular Italy. Hystrix, n.s. 25 (1): 5960. http://dx.doi.org/10.4404/hystrix-25.1-9248

Felten, H., Helfricht, A. \& Storch, G. 1973. Die Bestimmung der europäischen Fledermäuse nach der distalen Epiphyse des Humerus. Senckenbergiana Biologica 54: 291-297.

FERnÁNDEZ-JALVo, Y. \& Andrews, P. 1992. Small Mammal Taphonomy of Gran Dolina. Atapuerca (Burgos), Spain. Journal of Archaeological Science 19: 407-428. http://dx.doi.org/10.1016/0305-4403(92)90058-B

Guillem Calatayud, P.M. 1997. Estudio tafonómico de los quirópteros de Cova Negra (Xátiva): una confirmación del carácter corto y esporádico de las ocupaciones antrópicas. Archivo de Prehistoria Levantina 22: 4156.

Guerreschi, G., Catalani, P., Longo, G. \& Iannone, A. 1992. Grotta Bella (Terni). Una sequenza stratigrafica dal Neolitico inferiore all'età imperiale. I livelli preistorici. Bullettino Paletnologia Italiana, N.S. 83: $143-228$. 
García, A.M., Cervera, F. \& Rodríguez, A. 2005. Bat predation by long-eared owls in Mediterranean and temperate regions of Southern Europe. Journal Raptor Research 39: 445-453.

Ghazali, M.A. 2009. Identification of Myotis Blythii and M. Myotis (Chiroptera, Vespertilionidae) from Eastern Europe based on the measurements of lower teeth. Vestnik zoologii 43: 403-408. http://dx.doi. org/10.2478/v10058-009-0018-6

HAND, S.J. \& GRANT-Mackie, J.A. 2012. Late Holocene bats of Mé Auré Cave, New Caledonia: evidence of human consumption and a new species record from the recent past. The Holocene 20:79-90. http://dx.doi. org/10.1177/0959683611409783

HARris, E.C. 1979. Principles of archaeological stratigraphy. Academic Press, London, 170 pp.

HoráčeK, I., HanÁk, V. \& GAisler, J. 2000. Bats of the Palearctic Region: a taxonomic and biogeographic review. In: B.W. Wołoszyn (ed.), Proceedings of theVIIIth EBRS, 1, pp. 11-157.

Jullien, R. 1972. Les chiroptères du Wurmien II de la grotte de l'Hortus (Valflaunès, Hérault). Etudes Quaternaires 1: $247-265$.

KowALSKI, K. 1995. Taphonomy of bats (Chiroptera). Geobios, M.S. 18: 251-256. http://dx.doi.org/10.1016/ S0016-6995(95)80172-3

LANZA, B. 1959. Chiroptera Blumenbach, 1779. In: A. Toschi, B. Lanza, Fauna d'Italia, vol. IV, Mammalia, generalità, Insectivora, Chiroptera, Calderini, Bologna, pp. 187-473.

LanzA, B. 2012. Fauna d'Italia. Mammalia V. Chiroptera. Edizioni Calderini de Il Sole 24 Ore, Milano-Bologna, $800 \mathrm{pp}$.

Lanza, B. \& Agnelli, P. 2002. Chirotteri, Chiroptera Blumenbach, 1779. In: M. Spagnesi, A.M. De Marinis (eds.), Mammiferi d'Italia. Quaderni di Conservazione della Natura 14: 44-142.

López-García, J.M. \& Sevilla, P. 2012. La contribución de los fósiles a la reconstrucción de las dinámicas de población de murciélagos. Barbastella 5 (1): 12-18. http://dx.doi.org/10.14709/BarbJ.5.1.2012.03

Mangerud, J., Andersen, S.T., Berglund, B.E. \& Donner, J.J. 1974. Quatcrnary stratigraphy of Norden, a proposal for terminology and classification. Boreas 3: $109-128$

MeIN, P. 1975. Les Chiroptères (Mammalia) du gisement pléistocène moyen des Abimes de la Fage à Noailles (Corrèze). Nouvelles Archives du Museum d'Histoire Naturelle de Lyon 13: 57-67.

Mein, P. \& Tupinier, Y. 1977. Formule dentaire et position systematique du Minioptere (Mammalia, Chiroptera). Mammalia 41: 207-210.
Miller, G.S. 1912. Catalogue of the Mammals of Western Europe (Europe exculsive of Russia). British Museum (Nat. Hist.), London, 1019 pp. http://dx.doi. org/10.1515/mamm.1977.41.2.207

Miller-Butterworth, C.M., Murphy, W.J., O'Brien, S.J., Jacobs, D.J., Springer, M.S. \& Teeling, E.C. 2007. A Family Matter: Conclusive Resolution of the Taxonomic Position of the Long-Fingered Bats, Miniopterus. Molecular Biology and Evolution 24: 1553-1561.

Mucedda, M., Pidinchedda, E. \& Bertelli, M.L. 2009. Status del Rinolofo di Mehely (Rhinolophus mehelyi) (Chiroptera, Rhinolophidae) in Italia. In: G. Dondini, G. Fusco, A. Martinoli, M. Mucedda, D. Russo, M. Scotti, S. Vergari (eds.), Chirotteri italiani: stato delle conoscenze e problemi di conservazione - Atti del $2^{\circ}$ Convegno Italiano sui Chirotteri, pp. 89-98.

NATURA 2000 DATABASE, http://natura2000.eea.europa.eu/ Natura2000, consulted on 07/02/2015.

Niethammer, J. \& Krapp, F. 2001. Handbuch der Säugetiere Europas. Bd. 4: Fledertiere, Teil I: Chiroptera I. AULA-Verlag, Wiebelsheim, 603 pp.

Orombelli, G. \& Ravazzi, C. 1996. The Lateglacial and early Holocene: chronology and paleoclimate. Il Quaternario 9: 439-444.

PAPI, F. 2004. Contributo alla conoscenza della fauna cavernicola del Parco Naturale Regionale dei Monti Simbruini. Thesis in Biological Sciences, University of Roma "Tor Vergata".

RABEDER, G. 1972. Die Insectivoren und Chiropteren (Mammalia) aus dem Altpleistozan von Hundsheim (Niederosterreich). Annalen Naturhistorisches Museum Wien 76: 375-474.

RavAzZI, C. 2003. An overview of the Quaternary continental stratigraphic units based on biological and climatic events in Italy. Il Quaternario 16 (1bis): 11-18.

Rebello, H., Tarraso, P. \& Jones, G. 2010. Predicted impact of climate change on European bats in relation to their biogeographic patterns. Global Change Biology 16: 561-76. http://dx.doi. org/10.1111/j.1365-2486.2009.02021.x

Rolfo, M.F., Achino, K.F., Fusco, I., SAlari, L.\& Silvestri, L. 2013. La grotta Mora Cavorso a Jenne (Roma). I livelli dell'antica-media età del Bronzo. Rivista Scienze Preistoriche 63: 95-123.

Rolfo, M.F., Achino, K.F., Fusco, I., Silvestri, L. \& SALARI, L. 2012a. Grotta Mora Cavorso a Jenne, campagne di scavo 2009-2010. Lazio e Sabina 8: 77-90.

Rolfo, M.F., Isola, I., SAlari, L. \& Zanchetta, G. 2012 b. Stratigraphy, archeology and paleoclimate of Cavorso Cave (Central Italy): preliminary data. Abstracts Congresso AIQUA "The transition from natural to anthropogenic-dominated environmental change in 
Italy and the surrounding regions since the Neolithic", Pisa, 15-17 Febbraio 2012, p. 74.

Rolfo, M.F., Lelli, R., Martinez Labarga, C., Passacantando, D., Scorrano, G., Salari, L. \& RicKARDS, O. 2012c. La comunità neolitica di Grotta Mora Cavorso a Jenne (Roma): osservazioni deposizionali, paleobiologiche e faunistiche. Atti del $10^{\circ}$ Incontro di Studi sulla Preistoria e Protostoria in Etruria, Vol. I, pp. 131-143.

Rossina, V.V. 2006. Bats as an Indicator of Human Activity in the Paleolithic, Using the Example of Denisova Cave, Northwestern Altai. Paleontological Journal 40 (4): 5494-5500.

Rossina, V.V., Baryshnikov, G.F. \& Woloszyn, B.W., 2006. Dynamics of the Pleistocene bat fauna from the Matuzka Paleolithic site (Northern Caucasus, Russia) (Chiroptera). Lynx (Praha) N.S. 37: 229-240.

Ruedi, M., Arlettaz, R. \& Maddalena, T. 1990. Distinction morphologique et biochimique de deux especes jumelles de chauves-souris: Myotis myotis (Bork.) et Myotis blythi (Tomes) (Mammalia; Vespertilionidae). Mammalia 54: 415-429. http://dx.doi.org/10.1515/ mamm.1990.54.3.415

Russo, D., Cistrone, L. \& Carotenuto, L. 2010. I chirotteri della Riserva Naturale Regionale Montagne della Duchessa. ARP, Roma, 82 pp.

Salari, L. 2004. Contributo alla conoscenza dei resti ossei dei Chirotteri. Grotte e dintorni 8: 45-54.

SALARI, L. 2010. Lateglacial bats from the "M" layers of the Arene Candide Cave (Liguria, Italy). Rivista Italiana Paleontologia Stratigrafia 116: 119-138.

SAlari, L. 2011. Holocene bats from the Cocci Cave (Narni, Central Italy): palaeoecological and palaeobiogeographical implications. Revue de Paléobiologie 30: 605-618.

SALARI, L. 2012. I chirotteri tardopleistocenici della Caverna delle Arene Candide (Finale Ligure, Italia settentrionale): indicazioni paleoecologiche e paleobiogeografiche e interazione con gli esseri umani. In: J. De Grossi Mazzorin, D. Saccà, C. Tozzi (eds). Atti del $6^{\circ}$ Convegno Nazionale di Archeozoologia, Lucca, pp. 89-95.

SALARI, L. 2014. Holocene micromammals (Soricomorpha and Rodentia) from some caves of Central Italy. Revue de Paléobiologie 33: 79-96.

SALARI, L. in press. Micromammiferi di alcune grotte dell'Appennino centrale tra il Mesolitico e l'età del Bronzo. In: Atti del $7^{\circ}$ Convegno Nazionale di Archeozoologia, Ferrara-Rovigo 22-24 novembre 2012.

Salari, L. \& Di Canzio, E. 2009. I chirotteri del Pleistocene superiore e Olocene antico di alcune grotte dell'Italia centro-meridionale. Bollettino Museo Civico di
Storia Naturale Verona 33 (Geologia Paleontologia Preistoria): 3-25.

SAlari, L. \& Kotsakis, T. 2011. Late Pleistocene and Holocene bats of Latium (Central Italy). Il Quaternario 24: 121-129.

Salari, L., Kotsakis, T. \& Petronio, C. 2013. Early Pleistocene Bats from Pirro Nord (Apulia, Southern Italy). Palaeontographica, Abt. A 298: 55-72.

Salari, L., Passacantando, D. \& Rolfo, M.F. 2011. First data on the latest Pleistocene Mammals from Mora Cavorso Cave (Jenne, Latium, Central Italy). Il Quaternario, 24: 131-140.

SAlari, L., Zarattini, A. \& Rolfo, M.F. 2012. Nota preliminare sulla fauna del Neolitico antico di Grotta Mora Cavorso (Jenne, Lazio). In: J. De Grossi Mazzorin, D. Saccà, C. Tozzi (eds.), Atti del $6^{\circ}$ Convegno Nazionale di Archeozoologia, Lucca, pp. $171-174$.

Sevilla García, P. 1986. Identificación de los principales quirópteros ibéricos a partir de sus dientes aislados. Valor sistemático de los caracteres morfológicos y métricos dentarios. Doñana Acta Vertebrata 13: 111130.

Sevilla García, P. 1988. Estudio paleontologico de los quirópteros del Cuaternario español. Paleontologia i Evolució 22: 113-233.

Silvestri, L., Rolfo, M.F. \& SAlari, L. in press. La fauna della media età del Bronzo di Grotta Mora Cavorso (Jenne, Lazio). In: Atti $7^{\circ}$ Convegno Nazionale di Archeozoologia, Ferrara-Rovigo 22-24 novembre 2012.

Simmons, N.B. 2005. Order Chiroptera. In: D.E.Wilson \& D.A.M. Reeder (eds.), Mammal species of the world. A taxonomic and geographic reference. $3^{\text {rd }}$ Ed., Johns Hopkins University Press, Baltimore, Vol. 1, pp. 312529.

Taliana, D., Alessio, M., Allegri, L., Capasso Barbato, L., De Angelis, M.C., Esu, D., Girotti, O., Gliozzi, E., Improta, S., Mazzini, I. \& Sardella, R. 1996. Preliminary results on the "Grotta del Lago" Holocene deposits (Triponzo, Nera River Valley, Umbria, Central Italy). Il Quaternario 9: 745-752.

TopáL, G. \& Tusnadi, G. 1963.- Data for craniometric investigation of Myotis myotis Borkh. and Myotis oxygnathus Montic. in Hungary. Annales HistoricoNaturales Musei Nationalis Hungarici 55: 543-549.

Vernier, E. 1993. Predazione di Chirotteri da parte del Barbagianni (Tyto Alba) in Italia. Hystrix, n.s. 5: 105107. http://dx.doi.org/10.4404/hystrix-5.1-2-4010

Wilkens, B. 1996. Le faune. In T. Di Fraia, R. Grifoni Cremonesi (eds), La Grotta Sant'Angelo sulla Montagna dei Fiori (Teramo), IEPI, Pisa-Roma, pp. 277-293. 